\title{
PENGARUH STRUKTUR MODAL, STRUKTUR ASET DAN STRUKTUR KEPEMILIKAN TERHADAP RISIKO KEUANGAN PADA PERUSAHAAN PROPERTY DAN REAL ESTATE YANG TERDAFTAR DI BEI PERIODE 2015-2017.
}

\author{
Shafara Ahmadea Widanastiti ${ }^{1}$ \\ Puji Rahayu ${ }^{2}$ \\ ${ }^{1}$ Prodi Akuntansi Fakultas Ekonomi Universitas Islam Kadiri \\ ${ }^{2}$ Prodi Akuntansi Fakultas Ekonomi Universitas Islam Kadiri
}

\begin{abstract}
Abstrak
Penelitian ini bertujuan untuk mengetahui pengaruh struktur modal, struktur aset dan struktur kepemilikan terhadap risiko keuangan pada Perusahaan Property dan Real Estate yang terdaftar di BEI Periode 2015-2017. Variabel independen yang digunakan dalam penelitian ini adalah struktur modal, struktur aset dan struktur kepemilikan. Variabel dependen yang digunakan dalam penelitian ini adalah risiko keuangan. Penelitian ini menggunakan data sekunder dengan jumlah sampel 18 perusahaan. Analisis data digunakan dengan regresi linier berganda dengan bantuan SPSS'16 dan juga menggunakan teknik purposive sampling.

Hasil penelitian menunjukkan bahwa secara parsial struktur modal tidak berpengaruh terhadap risiko keuangan, struktur aset berpengaruh positif terhadap risiko keuangan dan struktur kepemilikan berpengaruh positif terhadap risiko keuangan. Secara simultan struktur modal, struktur aset dan struktur kepemilikan berpengaruh terhadap risiko keuangan.

Kemampuan prediksi dari ketiga variabel terhadap risiko keuangan diperoleh R Square sebesar 0,301 atau 30,1\% dapat disimpulkan bahwa variabel struktur modal, struktur aset dan struktur kepemilikan mampu mempengaruhi risiko keuangan sebesar 30,1\% dan sisanya 69,9\% dipengaruhi oleh variabel lain diluar penelitian.
\end{abstract}

Kata Kunci : struktur modal, struktur aset, struktur kepemilikan dan risiko keuangan. 


\begin{abstract}
This study aims to determine the effect of capital structure, asset structure and ownership structure on financial risk in Property and Real Estate Companies listed on the Stock Exchange for the 2015-2017 period. The independent variables used in this study are capital structure, asset structure and ownership structure. The dependent variable used in this study is financial risk. This study uses secondary data with a sample of 18 companies. Data analysis was used with multiple linear regression with the help of SPSS16 and also using purposive sampling technique.

The results of the study show that partially the capital structure does not affect financial risk, the asset structure has a positive effect on financial risk and the ownership structure has a positive effect on financial risk. Simultaneously capital structure, asset structure and ownership structure influence financial risk.

Predictive ability of the three variables on financial risk obtained by $R$ Square of 0.301 or $30.1 \%$ can be concluded that the variable capital structure, asset structure and ownership structure are able to influence financial risk by $30.1 \%$ and the remaining $69.9 \%$ is influenced by other variables outside research.
\end{abstract}

Keywords: capital structure, asset structure, ownership structure and financial risk.

\title{
I. PENDAHULUAN
}

Persaingan bisnis di Indonesia saat ini sangatlah ketat. Banyak perusahaan kecil maupun perusahaan besar yang melakukan persaingan untuk mempertahankan kelangsungan hidup perusahaan. Salah satunya adalah perusahaan di bidang property dan real estate. Perusahaan real estate adalah perusahaan yang bergerak di bidang kontruksi tanah dan bangunan, dimana perusahaan real estate ini dari tahun ke tahun semakin berkembang. Seperti saat ini sudah banyak perusahaan dibidang property dan real estate yang mekakukan pengembangan usahanya dengan membangun berbagai perumahan dan pertokoan yang tidak hanya berada di kota besar tetapi juga di desa. Hal ini juga di dukung dengan program pemerintah yaitu rumah sederhana bersubsidi. Adanya kebijakan program rumah sederhana bersubsidi diharapkan dapat memberikan manfaat bagi perekonomian bangsa dan menarik investasi asing masuk ke Indonesia, selain itu juga dapat meningkatkan pendapatan pajak daerah maupun negara. Hal ini menunjukkan bahwa perusahaan real estate memiliki daya tarik untuk berinvestasi serta menjadi ujung tombak perekonomian di Indonesia (okezone.com).

Tidak terlepas dari hal tersebut, Indonesia telah dipadati oleh perusahaan property dan real estate berskala besar yang sudah terdaftar sebagai perusahaan go public, dimana perusahaan yang sudah go public diwajibkan untuk menyampaikan laporan keuangannya kepada publik. Laporan keuangan berfungsi untuk menunjukkan informasi dan posisi keuangan yang disajikan untuk pihakpihak yang berkepentingan atau investor. Dimana investor merupakan orang yang 
menanamkan modal di suatu perusahaan. Modal menjadi salah satu aspek penting bagi perusahaan. Perusahaan harus menentukan seberapa banyak modal yang diperlukan untuk membiayai kegiatan operasionalnya. Adanya investor yang menanamkan modal akan membuat perusahaan memiliki struktur modal yang kuat.

Struktur modal adalah perbandingan atau imbangan pendanaan jangka panjang perusahaan yang ditunjukkan oleh perbandingan hutang jangka panjang terhadap modal sendiri (Harjito dan Martono, 2013). Penentuan struktur modal bagi suatu perusahaan merupakan salah satu bentuk keputusan keuangan yang penting, karena keputusan ini dapat berpengaruh terhadap pencapaian tujuan manajemen keuangan perusahaan. Struktur modal merupakan masalah penting bagi setiap perusahaan karena baik buruknya struktur modal perusahaan akan mempunyai efek langsung terhadap posisi finansial perusahaan tersebut. Jika suatu perusahaan memiliki struktur modal yang tidak baik, yaitu yang memiliki hutang yang sangat besar akan memberikan beban yang berat kepada perusahaan tersebut (Sari, 2013). Struktur modal itu sendiri ada dua yaitu modal sendiri dan modal asing atau modal yang berasal dari pinjaman. Modal sendiri adalah modal yang murni dimiliki oleh perusahaan, sedangkan modal asing adalah modal yang diperoleh dari pihak luar perusahaan. Untuk mempermudah perusahaan dalam memperoleh pinjaman, perusahaan harus memiliki struktur aset yang baik.

Struktur aset adalah komposisi relatif asset tetap yang dimiliki oleh perusahaan terhadap total aset. Saat perusahaan memiliki asset yang besar diharapkan hasil operasional yang dihasilkan juga semakin besar. Dengan adanya pertambahan aset perusahaan diikuti dengan peningkatan hasil maka akan menambah kepercayaan pihak luar terhadap perusahaan (Srimindarti dan Hardiningsih, 2017). Aset yang ditampilkan pada laporan keuangan perusahaan akan meyankinkan pihak kreditur, sehingga akan memudahkan pihak kreditur untuk menilai kinerja perusahaan dan perusahaan tersebut kemungkinan dengan mudah mendapatkan pinjaman. Aset dalam perusahan tidak sepenuhnya milik perusahaan itu sendiri, melainkan ada beberapa aset yang dimiliki oleh perusahaan lain. Contohnya adalah saham yang termasuk dalam aset lancar, dimana besarnya saham akan mempengaruhi presentase kepemilikan dalam struktur kepemilikan perusahaaan.

Struktur kepemilikan merupakan berbagai macam bentuk dari kepemilikan suatu perusahaan atau presentase kepemilikan saham yang dimiliki oleh pemegang saham internal dan pemegang saham eksternal (Jensen dan Meckling, 1976 dalam Wongso, 2013). Struktur kepemilikan dapat dijelaskan dari dua sudut pandang, yaitu pendekatan keagenan dan pendekatan informasi asimetri. Menurut pendekatan keagenan, struktur kepemilikan untuk mengurangi konflik kepentingan antara manajer dengan pemegang saham. Pendekatan ketidakseimbanagan informasi antara insiders dan outsiders melalui pengungkapan informasi di dalam pasar modal. Struktur kepemilikan dipercaya memiliki kemampuan untuk memengaruhi jalannya perusahaan yang nantinya dapat mempengaruhi kinerja serta risiko yang dihadapi perusahaan contohnya risiko keuangan.

Risiko keuangan adalah tambahan risiko yang dibebankan kepada para pemegang saham biasa sebagai hasil dari keputusan untuk mendapatkan pendanaan melalui hutang (Brigham dan Houston, 2011). Pembiayaan dengan 
hutang umumnya akan meningkatkan tingkat pengembalian yang diharapkan untuk suatu investasi, tetapi utang juga meningkatkan tingkat risiko investasi bagi pemilik perusahaan, yaitu para pemegang saham. Para pemegang saham biasa pada umumnya menuntut kompensasi, dalam bentuk premi risiko untuk risiko yang lebih tinggi. Dengan demikian tingkat pengembalian yang disyaratkan akan semakin tinggi. Untuk memperoleh uang yang dibutuhkan perusahaan dapat menerbitkan saham biasa, meminjam uang atau menggunakan kombinasi hutang dan ekuitas.

Struktur modal, struktur aset dan struktur kepemilikan memiliki hubungan yang sangat kuat terhadap risiko keuangan. . Suatu perusahaan seperti perusahaan property dan real estate untuk memenuhi kebutuhan operasional keuangannya membutuhkan modal, dengan adanya struktur modal yang optimal tujuan perusahaan akan tercapai. Selain struktur modal perusahaan propeerty dan real estate juga memiliki struktur aset, dengan memiliki aset yang lebih besar maka perusahaan akan dengan mudah mendapatkan pinjaman dengan menggunakan aset tersebut sebagai jaminan hutang. Selain struktur modal dan struktur aset, struktur kepemilikan juga mempengaruhi risiko keuangan. Struktur kepemilikan merupakan pemisahan antara pemilik perusahaan internal dengan pemilik eksternal seperti investor. Dalam perusahaan property dan real estate terdapat berbagai struktur kepemilikan salah satunya adalah kepemilikan institusional. Dengan adanya struktur kepemilikan maka perusahaan dapat dengan mudah memisahkan kepemilikan sesuai dengan fungsinya.

Berdasarkan uraian dan pertimbangan di atas, maka peneliti memilih judul penelitian "Pengaruh Struktur Modal, Struktur Aset dan Struktur Kepemilikan Terhadap Risiko Keuangan Pada Perusahaan Property dan Real Estate yang Terdaftar Di BEI Periode 2015-2017".

\section{Tinjauan Pustaka}

\section{Struktur Modal}

Menurut Ambarwati (2010), struktur modal adalah kombinasi atau perimbangan antara utang dan modal sendiri (saham preferen dan saham biasa) yang digunakan untuk merencanakan pendapatan modal. Sedangkan menurut Fahmi (2017), struktur modal adalah sebagai berikut : Struktur modal merupakan rasio yang menunjukkan bagaimana perusahaan mampu untuk mengelola hutangnya dalam rangka memperoleh keuntungan dan juga mampu untuk melunasi kembali hutangnya. Menurut Harjito dan Martono (2013), struktur modal adalah perbandingan atau imbangan pendanaan jangka panjang perusahaan yang ditunjukkan oleh perbandingan hutang jangka panjang terhadap modal sendiri.

Menurut Hery (2015) struktur modal dapat ditentukan dengan menggunakan rumus sebagai berikut:

Keterangan :

$$
\text { DER }=\frac{\text { Total Utang }}{\text { Total Modal }}
$$

DER = Debt to Equity Ratio

\section{Struktur Aset}

Menurut Brigham dan Houston (2011), struktur aset merupakan dimana perusahaan yang asetnya memadai untuk digunakan sebagai jaminan pinjaman 
cenderung akan cukup banyak menggunakan hutang. Sedangkan menurut Sitanggang (2013) struktur aktiva merupakan komposisi aktiva tetap berwujud perusahaan yang jumlahnya besar akan mempunyai peluang untuk memperoleh tambahan modal dengan hutang, karena aktiva tetap dapat dijadikan sebagai jaminan untuk memperoleh hutang. Menurut Riyanto, 1997 dalam Sari (2013) struktur aktiva adalah penentuan berupa besar aslokasi untuk masing-masing komponen aktiva, baik dalam aktiva lancar maupun dalam aktiva tetap.

Struktur aset dapat diukur dengan menggunakan hasil bagi antara total aktiva tetap terhadap total aktiva. Secara sistematis struktur aktiva menurut Syamsudin (2011) diformulasikan sebagai berikut :

\section{Struktur Kepemilikan}

$$
\text { Struktur Aktiva }=\frac{\text { Total Aktiva Tetap }}{\text { Total Aktiva }}
$$

Menurut Sugiarto (2009), Struktur kepemilikan adalah struktur kepemilikan saham yaitu perbandingan jumlah saham yang dimiliki oleh orang dalam (insider) dengan jumlah saham yang dimiliki oleh investor. Atau dengan kata lain struktur kepemilikan saham adalah proporsi kepemilikan instituisonal dan kepemilikan manajemen dalam kepemilikan saham perusahaan. Dalam menjalankan kegiatannya suatu perusahaan diwakili oleh direksi (agents) yang ditunjuk oleh pemegang saham (principals)". Sedangkan menururt Sudana (2011), struktur kepemilikan merupakan pemisahan antara pemilik perusahaan dan manajer perusahaan. Pemilik atau pemegang saham adalah pihak yang menyertakan modal ke dalam perusahaan, sedangkan manajer adalah pihak yang ditunjuk pemilik dan diberi kewenangan mengambil keputusan dalam mengelola perusahaan, dangan harapan manajer bertindak sesuai dengan kepentingan pemilik". Menurut Faisal (dalam Sabrinna 2010), struktur kepemilikan merupakan suatu mekanisme untuk mengurangi konflik antara manajmen dan pemegang saham.

Menurut Sugiarto (2009) struktur kepemilikan dipisahkan menjadi dua fungsi yaitu kepemilikan institusional dan manajerial. Dalam penelitian ini peneliti menggunakan struktur kepemilikan institusional untuk mengukur struktur kepemilikan karena kepemilikan institusional merupakan kepemilikan saham yang dimiliki oleh perusahaan lain yang berinvestasi pada suatu perusahaan dan umumnya bertindak sebagai pihak yang memonitor perusahaan. Menurut Sugiarto (2009), struktur kepemilikan institusional diukur sesuai dengan proporsi kepemilikan saham yang dimiliki oleh institusional Kepemilikan Institusional. Berikut adalah perhitungan struktur kepemilikan institusional :

$$
\text { Kepemiikan Institusional }=\frac{\text { kepemilikan saham institusional }}{\text { jumlah saham yang beredar }} \times 100 \%
$$

Menurut Sugiono (2009), risiko keuangan merupakan suatu faktor yang mempengaruhi laba bersih yang timbul sebagai akibat dari penggunaan modal asing (luar) yang menghasilkan beban bunga (financial leverege). Sedangkan menurut Brigham dan Houston (2011), risiko keuangan adalah tambahan risiko yang dibebankan kepada para pemegang saham biasa sebagai hasil dari keputusan untuk mendapatkan pendanaan melalui hutang. Menurut Siahaan (2013), risiko 
keuangan adalah risiko yang dapat menimbulkan penurunan arus, nilai atau penghasilan perusahaan dalam jumlah yang tidak diharapkan, di mana jumlah tersebut dipengaruhi pergerakan harga salah satu atau lebih dari satu aktiva keuangan. Menurut Salim (2010) dan Effendi et.al (2009) perhitungan EPS adalah sebagai berikut:

$$
\text { EPS }=\frac{\text { Total Laba }}{\text { Total jumlah Saham }}
$$

Keterangan :

EPS = Earning per Share

\section{Kerangka Pikir}

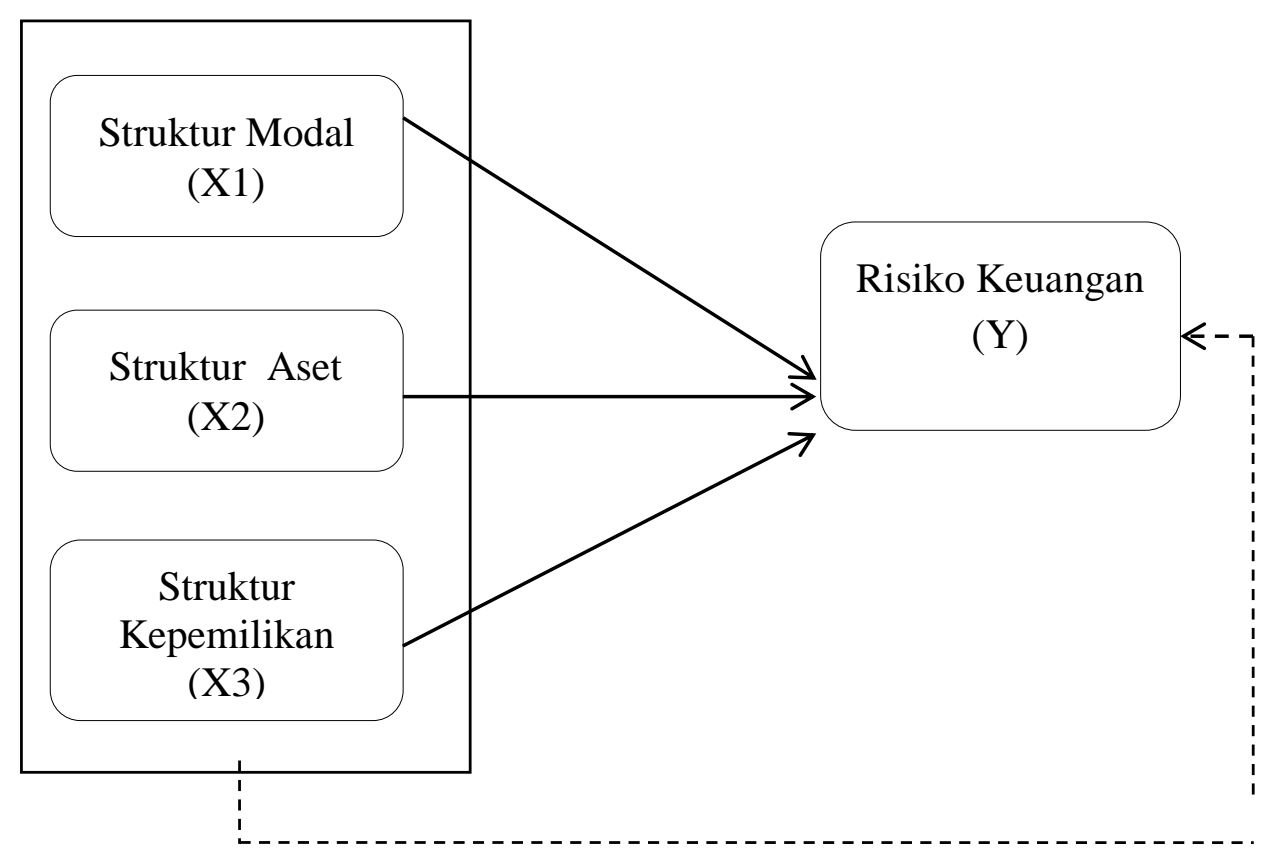

\section{METODE PENELITIAN}

Jenis penelitian ini menggunakan pendekatan kuantitatif. Pemilihan sampel akan menggunakan metode nonprobabilitas atau secara tidak acak, dengan menggunakan teknik purposive sampling. Jumlah sampel yang akan digunakan dalam penelitian berjumlah 18 perusahaan Property dan Real Estate, yang terdaftar di Bursa Efek Indonesia periode 2015-2017.

Sampel tersebut dipilih atau diaambil sesuai dengan kriteria-kriteria yang dibutuhkan dalam penelitian ini. Setelah data terkumpul peneliti melakukan analisis data yang diuraikan. Peneliti akan menggunakan analisis regresi linier berganda sebagai salah satu alat ukurnya. 


\section{HASIL PENELITIAN}

1. Analisis Regresi Linier Berganda

Tabel 4.5

\begin{tabular}{|l|r|r|r|}
\hline \multicolumn{1}{|c|}{ Variabel Bebas } & \multicolumn{1}{c|}{$\begin{array}{c}\text { Standardized } \\
\text { Coefficient Beta }\end{array}$} & \multicolumn{1}{c|}{$\mathrm{t}$} & \multicolumn{2}{c|}{ Sig. t } \\
\hline Constanta & & $-0,920$ & 0,063 \\
\hline Struktur Modal & 0,110 & 0,871 & 0,389 \\
\hline Struktur Aset & 0,434 & 3,436 & 0,001 \\
\hline Struktur Kepemilikan & & 2,518 & \\
\hline $\begin{array}{l}\text { Variabel Terikat } \\
\text { R }\end{array}$ & $=$ Risiko Keuangan \\
R Square & $=0,589$ \\
F hitung & $=0,347$ \\
Sig. F & $=7,616$ & & \\
\hline
\end{tabular}

Berdasarkan dari hasil output persamaan regresi linier berganda di atas diperoleh hasil persamaan sebagai berikut:

Risiko Keuangan = 0,110SM + 0,434SA + 0,325SK + e

\section{Uji Koefisien Determinasi (Adjusted $\boldsymbol{R}^{2}$ )}

Berdasarkan hasil perhitungan model regresi diperoleh nilai koefisien determinasi $\left(\mathrm{R}^{2}\right)$ sebesar 0,301. Dapat disimpulkan bahwa besar pengaruh variabel independen yaitu struktur modal, struktur aset dan struktur kepemilikan terhadap variabel dependen yaitu risiko keuangan dapat diterangkan oleh model regresi sebesar 30,1\% sedangkan sisanya 69,9\% diterangkan oleh faktor lain yang tidak dimasukan dalam penelitian.

\section{Uji Regresi Parsial (Uji t)}

Berdasarkan hasil uji regeresi nilai signifikansi struktur modal pada uji $\mathrm{t}$ lebih dari $0,05(0,389>0,05)$ maka H0 diterima dengan nilai beta sebesar 0,110. Artinya struktur modal tidak berpengaruh terhadap risiko keuangan. Nilai signifikansi struktur aset pada uji t adalah kurang dari $0,05(0,001<0,05)$ maka H0 ditolak dengan nilai beta sebesar 0,434. Artinya variabel struktur aset berpengaruh (positif) terhadap risiko keuangan. Nilai signifikansi struktur kepemilikan pada uji $\mathrm{t}$ adalah kurang dari $0,05(0,016<0,05)$ maka H0 ditolak dengan nilai beta sebesar 0,325.Artinya struktur kepemilikan berpengaruh (positif) terhadap risiko keuangan.

\section{Uji Signifikansi Simultan (Uji F)}

Uji F untuk mengetahui apakah secara bersama-sama variabel struktur modal, struktur aset dan struktur kepemilikan berpengaruh secara signifikan atau tidak terhadap risiko keuangan. Pengambilan keputusan berdasar signifikansi, jika $<$ 0,05 maka H0 ditolak, dan jika signifikansi $>0,05$ maka H0 diterima. Karena nilai signifikansi pada uji F kurang dari $0,05(0,000<0,05)$ maka HO ditolak. Artinya variabel struktur modal, struktur aset dan struktur kepemilikan secara bersama-sama berpengaruh secara signifikan terhadap risiko keuangan. 


\section{KESIMPULAN DAN SARAN}

\section{Kesimpulan}

a. Struktur modal tidak berpengaruh terhadap risiko keuangan. Nilai signifikansi struktur modal yang lebih besar dari nilai signifikansi yang diharapkan menujukkan bahwa hipotesis pertama ditolak, sehingga Struktur Modal tidak bisa digunakan untuk memprediksi Risiko Keuangan Perusahaan Property dan Real Estate yang Terdaftar di Bursa Efek Indonesia Periode 2015-2017.

b. Struktur aset berpengaruh signifikan terhadap risiko keuangan. Nilai signifikansi struktur aset lebih kecil dari nilai signifikansi yang diharapkan menunjukkan bahwa hipotesis kedua diterima, sehingga Struktur Aset dapat digunakan untuk memprediksi Risiko Keuangan Perusahaan Property dan Real Estate yang Terdaftar di Bursa Efek Indonesia Periode 2015-2017.

c. Struktur kepemilikan berpengaruh signifikan terhadap risiko keuangan. Nilai signifikansi Kepemilikan Institusional yang lebih kecil dari nilai signifikansi yang diharapkan menunjukkan bahwa hipotesis ketiga diterima, sehingga Kepemilikan Institusional dapat digunakan untuk memprediksi Risiko Keuangan Perusahaan Property dan Real Estate yang Terdaftar di Bursa Efek Indonesia Periode 2015-2017.

d. Struktur Modal, Struktur Aset dan Struktur Kepemilikan secara simultan berpengaruh terhadap Risiko Keuangan. Nilai signifikansi yang lebih kecil dari nilai batas signifikansi menujukan bahwa hipotesis keempat diterima, sehingga model regresi ini layak digunakan untuk memprediksi Risiko Keuangan Perusahaan Property dan Real Estate yang Terdaftar di Bursa Efek Indonesia Periode 2015-2017.

\section{Saran}

a. Bagi Perusahaan yang Sejenis

Risiko keuangan merupakan masalah yang penting bagi setiap perusahaan karena risiko keuangan menyangkut bagaimana keadaan perusahaan tersebut dari beberapa hal yang mempengaruhi risiko keuangan. Oleh sebab itu sebaiknya pihak manajemen dari perusahaan Property dan Real Estate harus mempertimbangkan variabel yang mempengaruhi risiko keuangan seperti struktur aset dan struktur kepemilikan sehingga dapat menentukan risiko keuangan yang akan dihadapi perusahaan.

b. Bagi Peneliti Lebih Lanjut

Nilai adjusted $R^{2}$ dari hasil penelitian ini adalah rendah yaitu sebesar $30,1 \%$ dan sisanya $69,9 \%$ yaitu dapat dijelaskan dengan variabel lain.Agar hasil penelitian lebih tepat dalam memprediksi risiko keuangan, disarankan bagi peneliti selajutnya untuk menambahkan periode penelitian. Selain itu, peneliti yang tertarik untuk melakukan penelitian yang mempengaruhi risiko keuangan, disarankan untuk mengganti beberapa variabel atau mengurangi variabel independen yang diinginkan untuk mengetahui faktor-faktor yang dapat mempengaruhi risiko keuangan.

\section{DAFTAR PUSTAKA}


Jurnal Cendekia ARuntansi Vol. 1 NNo. 1

Ambarwati, Sri Dwi Ari (2010), Manajemen Keuangan Lanjutan, Edisi Pertama, Yogyakarta: Graha Ilmu.

Brigham, Eugene F \& Houston, Joel F (2011), Fundamentals of Financial Management, (H. Wibowo, Trans), Jakarta: Erlangga.

Effendy Marwan, dkk , (2009), Pengaruh Struktur Modal terhadap Risiko Keuangan, [Online], Tersedia: http://scholar.google.co.id, [30 Oktober 2018].

Fahmi, Irham (2017), Analisis Laporan Keuangan, Bandung: Alfabeta.

Harjito, D. A \& Martono (2013), Manajemen Keuangan, Yogyakarta: EKONISIA.

Hery (2015), Pengantar Akuntansi, Jakarta: PT.Grasindo.

Sabrinna, Anindhita Ira, (2010), Pengaruh Corporate Governance dan Struktur Kepemilikan terhadap Kinerja Perusahaan, [Online], Tersedia: https://scholar.google.co.id, [21 Desember 2018].

Salim, Joko, (2010), Cara Gampang Bermain Saham, Jakarta: Visimedia.

Sari, Devi Verena, (2013), Pengaruh Profitabilitas, Pertumbuhan Aset, Ukuran Perusahaan, Struktur Aktiva dan Likuiditas terhadap Struktur Modal, [Online], Tersedia: https://scholar.google.co.id, [21 Desember 2018].

Siahaan, Hinsa, (2009), Manajemen Risiko pada Perusahaan dan Birokrasi, Jakarta: PT Elex Media Komputindo.

Sitanggang, J (2013), Manajemen Keuangan Perusahaan Lanjutan, Edisi kedua, Jakarta: Mitra Wacana Media.

Srimindarti, Ceacilia dan Pancawati Hardingsih, (2017), Pengaruh Struktur Asset Perusahaan terhadap Struktur Modal Dimoderasi Profitabilitas, [Online], Tersedia: https://scholar.google.co.id, [26 November 2018]

Sudana, I Made, (2011), Manajemen Keuangan Perusahaan Teori dan Praktek, Jakarta: Salemba Empat.

Sugiarto, (2009), Struktur Modal, Struktur Kepemilikan Perusahaan, permasalahan Keagenan dan Informasi Asimetri, Yogyakarta: Graha Ilmu.

Sugiono, Arief, (2009), Manajemen Keuangan Untuk Praktik Keuangan, Jakarta: Grasindo.

Wongso, Amanda, (2013), Pengaruh Kebijakan Dividen, Struktur Kepemilikan dan Kebijakan Hutang terhadap Nilai Perusahaan dalam Perspektif teori Agensi dan Teori Signaling, [Online], Tersedia: https://scholar.google.co.id, [21 Desember 2018]. 